\title{
Dedication of the New NBS Laboratories
}

On November 15, 1966, Secretary of Commerce John T. Connor dedicated the new ultra-modern facilities of the National Bureau of Standards at Gaithersburg, Md. This \$120 million laboratory complex serves as the nerve center of the Nation's measurement and standardization activities. With three Institutes devoted to Basic Standards, Materials Research, and Applied Technology, the Bureau's new home has been designed to meet the needs of today and the challenges of the future in the physical sciences.

Dedication ceremonies were held in a courtyard between the Bureau's new library and one of the laboratory buildings. In the center of the courtyard is an apple tree descended from the tree under which Sir Isaac Newton was sitting when, according to the story, an apple fell on his head, leading him to conceive the law of universal gravitation.

Surrounding this tree was an audience of 2500, including distinguished guests from government, industry, and the world scientific community. The Reverend Edward G. Latch, Chaplain of the House of Representatives, gave the invocation and the benediction. Intro- duced by Dr. A. Y. Astin, Director of the National Bureau of Standards, Secretary Connor said:

"It is no accident of history that the establishment of NBS in 1901 coincided with the beginning of America's transformation into the industrial giant of the twentieth century. . . . Today the demands made upon the Bureau and the nature of its program reflect the complexity of our atomic and space-age world."

The Secretary began his remarks with a message from President Johnson. The President noted that throughout its 65 years' existence the Bureau had advanced the frontiers of measurement in pace with the demands of science and industry; he extended his congratulations and best wishes for continuing achievement.

Secretary Connor stated that at age 65 the Bureau had significant accomplishments behind it and a future promising even greater contributions to the Nation. He noted that the new facilities are a symbol of the Bureau's future, but that the germ of future achievement lies in the members of the Bureau's staff.

In connection with the dedication, the Secretary

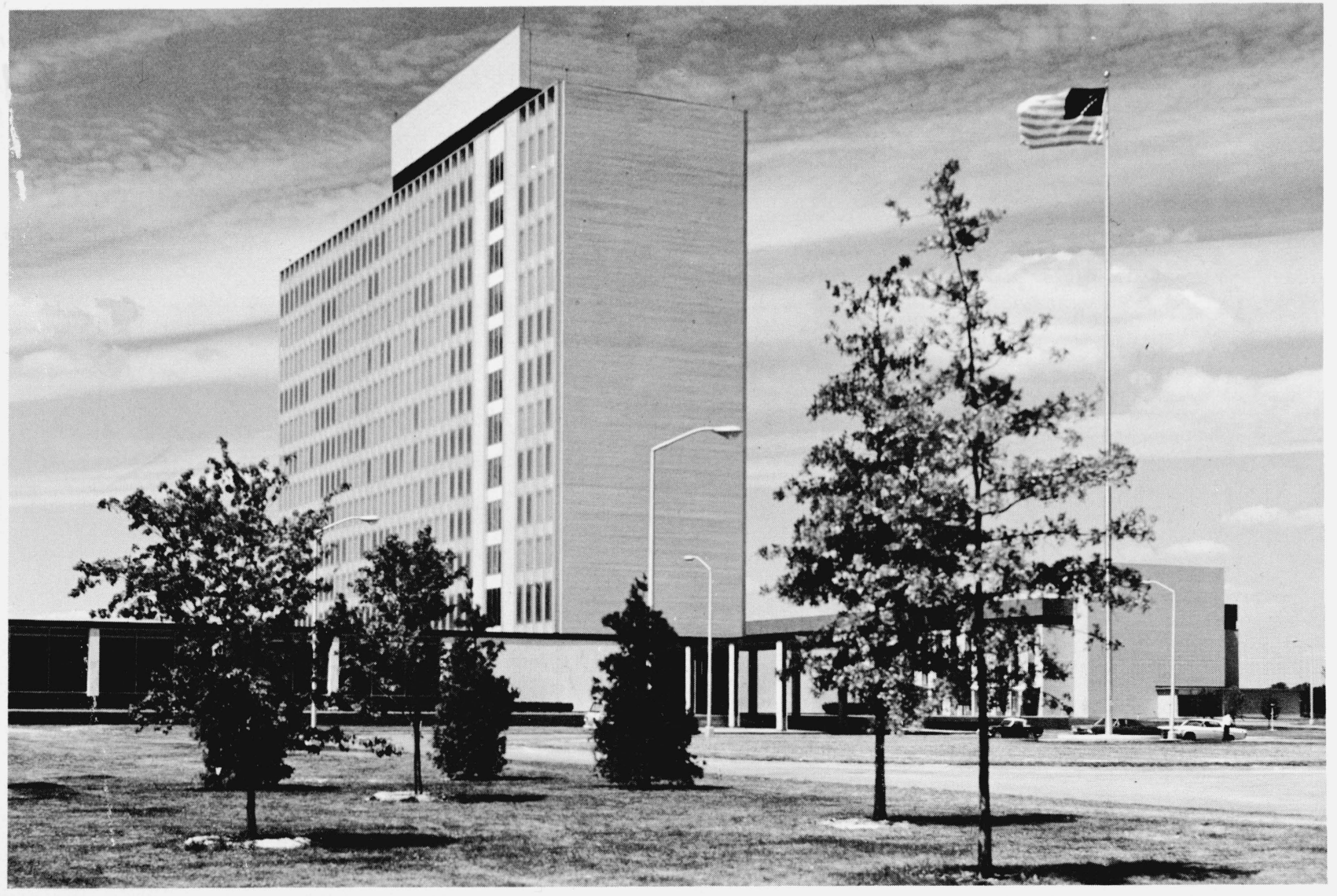

Eleven stories high, the Administration Building at the National Bureau of Standards' new site near Gaithersburg, Md., towers above the other buildings in the laboratory complex. The building houses the Director and his staff as well as other NBS activities not requiring laboratory space. 

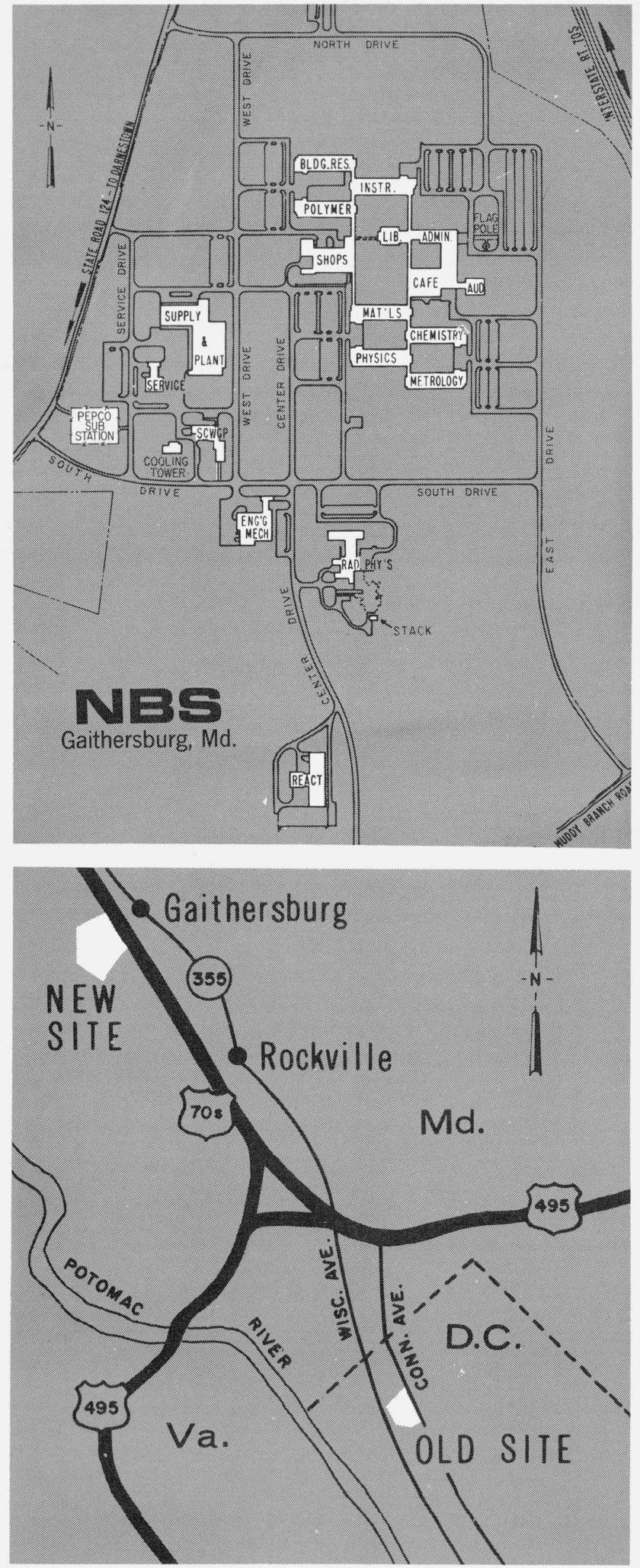

The new NBS site is 20 miles northwest of the old Washington site, at the Darnestown exit of Interstate Highway 70S. It borders and is west of $70 \mathrm{~S}$ and Gaithersburg, Md. The plan view shows the layout of existing buildings. sponsored a Symposium on Technology and World Trade which was held at the Bureau during the two days following the dedication. It featured as speakers experts from industry, government, and education of many countries, attracting an attendance of nearly 500.

Following the dedication ceremonies, the invited guests were given a tour of the installation. On Saturday, November 19, the general public was invited to visit the new facilities and to view over 100 laboratories and demonstrations. In an eight-hour period over 20,000 people roamed the site. Some of the things they saw were a $100-\mathrm{ft}$ linear accelerator which produces one of the world's most intense electron beams; a recently completed high-flux research reactor; a 12-million pound capacity hydraulic testing machine; the NBS Museum containing historical instruments, equipment, standards, and materials pertaining to the Bureau's activities during its 65 -year history; a vault containing the national measurement standards-or parts symbolizing those standards; a demonstration of glass blowing techniques used to make highly unusual, and precise apparatus; and many of the Bureau's laboratories in the fields of metrology, electricity, mechanics, heat, atomic physics, radiation physics, analytical chemistry, physical chemistry, polymers, metallurgy, and building research.

By the close of 1966, transfer of the Bureau's Washington (D.C.) laboratories to the Gaithersburg site will be largely completed and most of the 2700 staff members will be relocated in $\mathbf{1 5}$ major buildings at the site. Of about 300 persons remaining at the Washington site, most will be relocated in new special-purpose laboratories now under construction at Gaithersburg. In addition, the Bureau will continue to maintain a staff of about 600 in Boulder, Colo., for work in radio standards and cryogenics, and a staff of about 300 at the Clearinghouse for Federal Scientific and Technical Information at Springfield, $\mathbf{V a}$., as well as small groups of employees at widely scattered field stations.

Although the Bureau is located $\mathbf{2 0}$ miles northwest of its old site, the mailing address remains: National Bureau of Standards, Washington, D.C. 20234. The new telephone number is (Area Code 301) 921-1000. To reach the Bureau by car, use the Darnestown exit on Interstate Highway 705. 